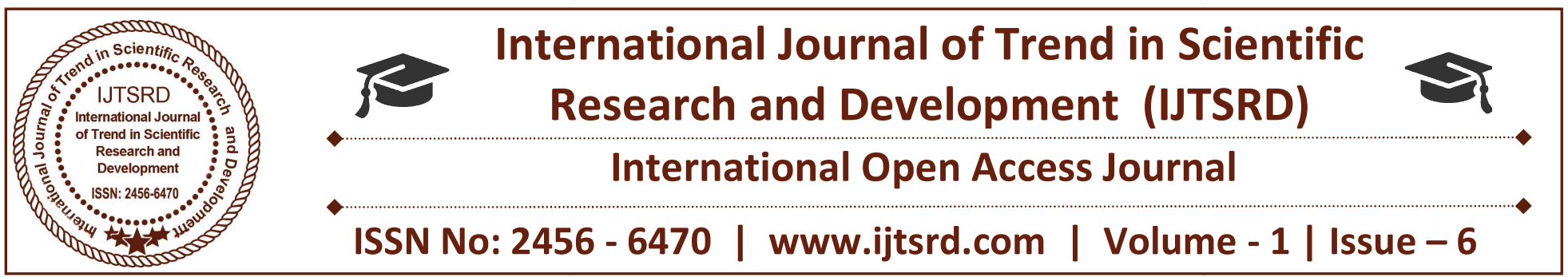

\title{
Islamic Banking and Corporate Social Responsibility: Growth and Future Potential with Special Reference to Prospects in India
}

\author{
Mehraj ud din wani \\ Research Scholar, Department of HRM \& OB, \\ Central University of Jammu, Jammu \& Kashmir, India
}

\begin{abstract}
Islamic banking system follows the principles, rules and guidelines of Islamic Law. Islamic banking has gained prominence among the major global financial institutions, like banking sector in USA and UK (Grail research). Under the Islamic law equal rights have been given to the individuals and it is mandatory for the bank to use the finance for the development of the society. Development and welfare are the major concerns of the Islamic law. Islamic banking in India has much more potential and growth, because of existence of huge Muslim population in the country. In India there is need to follow the rules of Islamic banking under Corporate Social Responsibility of any institution or bank. India has the potential for emerging as a significant market for Islamic banking institutions provided there should be a favourable change in regulatory environment and increased awareness among Muslims and other population of the country. The overall aim of the paper is to highlight potential of Islamic banking in India. There is an act of csr 2013 which says the company net worth to be 500 crore or more turnover of the company Rs 1000 crore or more; every qualifying company requires spending of at least $2 \%$ of its average net profit for the immediately preceding 3 financial years on corporate social responsibility activities.
\end{abstract}

Keywords: Islamic banking, corporate social responsibility

\section{Introduction}

Islamic banking is basically that method of banking which is based on Islamic law (shariah) where it is prohibited to go for "interest based banking". In Islamic point of view Allah has totally prohibits interest. Islamic banking has also the same purpose as of conventional banking but it operates all the business according to the rules and regulations of shariah, known as FIQH AL- MUAMLAT ( Islamic rules of transactions), the first Islamic banking experiment was done in 1963 by Ahmad El Najjar called "Nasir social bank" which is located in Egypt. Islamic banking currently operates in more than 50countries from Jakarta to Jordon, with assets estimated between $\$ 250$ million and \$ 300 billion.

\section{Principles of Islamic Banking}

The Islamic banking is normally used in deposit taking activities, custodial services and safe deposit.

$>$ In Islamic banking customers can withdraw money time.

Profit is shared between customer and bank based on a pre-agreed ratio.

\section{Islamic Banking and its effect on India}

In India there are around 140 million Muslims living in which $15 \%$ of the Islamic population. According to the Rating of Poor's ad standard ratings services the potential market is 4 trillion worldwide, so Islamic banking is a tool through which it can boost and enhance economic development in India. This will give some opportunities to the labourers and the working class belonging to the community. There is a growing concern and awareness about the concept among Indian banks and it is generally said that there 
is a huge potential market in India for Islamic banking. Islamic banking is approved by RBI; this development was expected after Dr Raghuram Rajan took over as governor of RBI, by replacing former governor D. Subbarao whose position on Islamic banking was not favourable. Dr. Raghuram Rajan, a farmer to take money from the bank but when the crops fail, they are left with no option other than death, " if there is Islamic banking this type of problem may not exist. With the help of Islamic banking operations could enable inclusive growth, easier access to credit, there are very little or no collateral requirements could help in penetration of banking facilities even in the lowest strata.

\section{Objectives of the Study}

$>$ To understand the concept of Islamic banking.

$>$ To highlight the growth and present status in India and worldwide.

$>$ To explore the basic principles and concepts in Islamic banking.

\section{Islamic Banking}

In India, Islamic banking question has been debated for a very long time. There are several attempts made for recognition of the Islamic banking model but it has not succeeded because of different regulatory constraints of RBI. A NBFC which is located in Kerala- cheramay financial services Ltd was set up which confirms with the shariah law in 2013.

Islamic banking in India is not applicable because of the following acts

$>$ banking regulation Act 1949

$>$ RBI Act, 1934

> Co-operative Societies Act 1961
A detailed and pioneer attempt of providing an outline of Islamic banking was made in Urdu by siddique in 1968. His Islamic banking model was based on two concepts Mudaraba and Shirka (a partnership of musharakh). As we talk about the present there are few studies which are discussing the Islamic view on CSR of Islamic banks from different angles. In this regard, farooq (2007) views performing corporate social responsibility by Islamic banks as fulfilling a collective religious obligation (fardh Kifayah) as financial institutions. There are early contributions on the subject of Islamic banking

Qureshi (1946) the book which was published called the theory of interest (Qureshi 1946), looked upon banking as a social service that should be sponsored by the government like public health and education.

Ahmed (1952) Ahmad in his book economies of Islam envisaged the establishment of Islamic banks on the basis of joint stock Company with limited liability.

By 1970, various Islamic banks had been established all over the world with the first private commercial bank in Dubai (1975), Bahrain Islamic bank (1979) and also the Faisal Islamic bank Sudan (1977). As we talk about today Islamic banking system is growing on a very fast pace. According to the world Islamic banking competitiveness report 2014-2015, the total Islamic banking assets attained compounded annual growth rate (CAGR) of around 17\% from 2009 to 2013, and the prediction of global profit pool of Islamic banks is set to triple by 2019 .

Rahmatullah professor, university of Calicut, "the Indian population is around 100 crore and Muslim population itself is about 15 crore so there is a vast field for Islamic banking in India.

\section{Review of Literature}

\begin{tabular}{|l|l|l|}
\hline S.NO & \multicolumn{1}{|c|}{ CONVENTIONAL BANKING } & \multicolumn{1}{c|}{ ISLAMIC BANKING } \\
\hline $\mathbf{1}$ & $\begin{array}{l}\text { The overall banking function is totally based } \\
\text { on manmade principles. }\end{array}$ & $\begin{array}{l}\text { The function and operating modes are based on } \\
\text { the principles of Islamic banking. }\end{array}$ \\
\hline $\mathbf{2}$ & $\begin{array}{l}\text { The objective is to maximizing profit without } \\
\text { any restriction. }\end{array}$ & $\begin{array}{l}\text { The basic objective is to maximize profit but } \\
\text { with to shariah restrictions. }\end{array}$ \\
\hline $\mathbf{3}$ & $\begin{array}{l}\text { The investor or customer is assured of a pre- } \\
\text { determined rate of interest. }\end{array}$ & $\begin{array}{l}\text { There is more concern on partnership business } \\
\text { rather than individual business. }\end{array}$ \\
\hline $\mathbf{4}$ & Conventional banking does not deal with zakat & It is based on those principles where zakat is \\
\hline
\end{tabular}


International Journal of Trend in Scientific Research and Development (IJTSRD) ISSN: 2456-6470

\begin{tabular}{|l|l|l|}
\hline & (Islamic tax). & mandatory. \\
\hline $\mathbf{5}$ & $\begin{array}{l}\text { Conventional banking practices are concerned } \\
\text { with elimination of risk when involve in any } \\
\text { transaction. }\end{array}$ & $\begin{array}{l}\text { Islamic banking practices are concerned with } \\
\text { risk bearing when involved in any transaction }\end{array}$ \\
\hline $\mathbf{6}$ & $\begin{array}{l}\text { Since income from the advances is fixed, it } \\
\text { gives little importance to developing expertise } \\
\text { in project appraisal and evaluations }\end{array}$ & $\begin{array}{l}\text { Since it shares profit and loss, the Islamic banks } \\
\text { pays greater attention to developing project } \\
\text { appraisal and evaluations. }\end{array}$ \\
\hline
\end{tabular}

\section{Islamic Banking - Potential in India}

The population of Muslim is about 154 million that is $13.2 \%$ of total population. As we talk about India it could be a significant market of Islamic banking institutions due to large Muslim population growth. According to the report of sachar committee Indian Muslims have a share of $7.4 \%$ in saving deposits while they get only $4.7 \%$ in credit. There are various studies which show that India has a very high potential of emerging as a significant market for Islamic banking. According to the report of market intelligence and data analysis services provider GRAIL Research, " Islamic banking is already fast gaining prominence among the global financial institutions especially in the countries like USA and UK and the concept has a huge potential market in India as well. Indian Muslims annually loose around Rs 63,700 crores i-e $27 \%$ of their own deposits. So that is why there should be more concern to Islamic banking services in India

Recently the RBI governor D- Subbarao recommended the government that there should be Islamic banking in India. In 2008, a high level committee on financial sector reform of the planning commission of India which is headed by renovest economist of India Dr. Raghuram Rajan has recommended to government of India that there should be interest free finance. As we talk about India there is already the presence of Islamic banking in the form of NBFC'S and Baitual Mal (Islamic treasury). But the business is yet very small.

\section{Research Methodology}

The research is basically based on secondary data, and the data are collected from different sources like newspapers, journals, RBI bulletin, Islamic institutes \& consultancies, various Islamic banks reports.

\section{Scope of Islamic Banking in India}

Islamic banking can contribute to economic growth in India, and also entrepreneurship in India would be encouraged as well. With the help of Islamic banking it will bring FDI in India.

Potential to contribute specially in the growth of weaker section in the society.

$>$ Potential to contribute by providing various loans to SME'S.

Potential to reduce unemployment throughout India.

$>$ Potential to provide low cost, easily available, capital to small poor entrepreneurs to India.

Islamic banking can provide various schemes to those customers who are not involved in banking yet with the Islamic restrictions.

Top 25 Islamic Investment Banks

\begin{tabular}{|c|c|c|c|c|}
\hline $\begin{array}{c}\text { Ranking By } \\
\text { ROA }\end{array}$ & TOP 500 & INSTITUTION & COUNTRY & $\begin{array}{c}\text { SHARIA assets \$ } \\
\text { m }\end{array}$ \\
\hline $\mathbf{1}$ & $\mathbf{4}$ & Al Rajhi bank & Saudi Arabia & $\mathbf{2 8 , 0 9 3 , 3 2}$ \\
\hline $\mathbf{2}$ & $\mathbf{9}$ & Qatar Islamic bank & Qatar & $\mathbf{4 , 0 9 0 , 2 5}$ \\
\hline $\mathbf{3}$ & $\mathbf{3 0}$ & Investment dar & Kuwait & $\mathbf{3 , 9 7 8 , 0 0}$ \\
\hline
\end{tabular}


International Journal of Trend in Scientific Research and Development (IJTSRD) ISSN: 2456-6470

\begin{tabular}{|c|c|c|c|c|}
\hline 4 & 32 & Abc Islamic bank & Bahrain & $3,484,00$ \\
\hline 5 & 34 & Ithamaar bank bsc & Bahrain & $3,179.00$ \\
\hline 6 & 40 & Arcaptia bank & Bahrain & 2,707.71 \\
\hline 7 & 42 & Qatar international Islamic bank & Qatar & $2,307.12$ \\
\hline 8 & 54 & shamil bank & Bahrain & $1,693.26$ \\
\hline 9 & 55 & Aayan leasing and investment & Kuwait & 1.642 .18 \\
\hline 10 & 56 & Gulf finance house bsc & Bahrain & $1,631.02$ \\
\hline 11 & 63 & National investment trust & Pakistan & $1,248.40$ \\
\hline 12 & 64 & Masraf al rayan & Qatar & $1,118.00$ \\
\hline 13 & 65 & Aref investment group & Kuwait & $1,179.60$ \\
\hline 14 & 70 & Qatar real estate investment co. & Qatar & $1,043.10$ \\
\hline 15 & 77 & Kuwait finance house & Malaysia & 855.49 \\
\hline 16 & 91 & Banque al Baraka D’ algerie & Algeria & 564.10 \\
\hline 17 & 92 & AlBaraka Islamic investment bank & Bahrain & 559.66 \\
\hline 18 & 93 & the international investment safat & Kuwait & 549.86 \\
\hline 19 & 94 & Khaleej finance \& investment co. & Bahrain & 519.67 \\
\hline 20 & 95 & Al salam bank & Bahrain & 500.15 \\
\hline 21 & 97 & First investment company & Kuwait & 482.40 \\
\hline 22 & 99 & European Islamic investment bank & Uk & 463.82 \\
\hline 23 & 101 & Al amin bank & Bahrain & 430.94 \\
\hline 24 & 104 & Gulf investment house & Kuwait & 388.27 \\
\hline 25 & 107 & Am investment group Bd & Malaysia & 353.93 \\
\hline
\end{tabular}

\section{Source: The Banker}

Corporate Social Responsibility of Islamic Banks from an Islamic Perspective

Islam does recognize the concept of legal entity, although the term legal entity is discussed in FIQH. Islam provides a complete and formal code of behaviour for life. Dsuki and Abdullah (2007b) stated that CSR concept is deeply inscribed in the shariah. Therefore any Islamic bank that claims or follow shariah based on Islamic principles should naturally practice CSR. As we talk about Islam it is not only restricted to only five (5) pillars. It involves all 
activities and daily routines in life. The overall concept of divine accountability is clearly stated in the Holy Quran in such versus as,

"When you are greeted with a greeting, greet in return with what is better than it or (at least) return it equally. Certainly Allah is ever a careful account taker of all things (Quran 4:86).

Zakat is one of five pillars of Islam. The zakat payment is mandatory for all Muslims who own wealth above the threshold (i-e 2.5\%) (Jehle, 1994, kamali, 2003). Basically zakat can be divided into two main parts one is called zakat ul fitr and zakat ul mal. Zakat ul fitr must be paid for charity at the end of every Ramadan (i-e fasting month in Islamic calendar), while zakat al-mal is the zakat on wealth (Ali and Myles, 2010).

\section{CONCLUSION}

With the help of Islamic banking it shall be the interest of India to allow Islamic banks to operate so that economy will be boost. India has the second largest Muslim population in the world, but a large section of Muslims not able to access banking services because of Islamic principles. Islamic banking not covering Muslim population but it is fulfilling the development of the society well. Various developed countries such as Germany, UK, and USA have embraced Islamic banking. it is not related to any particular religion but this can help us to operate and expand their network in the country along with traditional banks as the main focus of it is on social well being and wealth generation activities in the society.

\section{Suggestions}

As we talk about today Islamic banking is gaining much more importance in various parts of the world. If Islamic banking is opened in India it would be more beneficial to whole country's people. Interest free banking can help to eradicate poverty, improve education and generate employment.

\section{REFERENCES}

1) Delpachitra, S. (2013). Is Islamic banking capable of meeting corporate social responsibility, 10(2).

2) Dhanda, U., \& Sehrawat, M. (2015). Islamic Banking in India: An Alternative Banking System, 3(12), 171-180.

3) Di Bella, V., \& Al-Fayoumi, N. (2016). Perception of Stakeholders on Corporate Social
4) Qureshi, I. H. (1946). The Development of Islamic Culture in India. M. Ashraf.

5) Shamshad, A. (2011). Interest Free Islamic Banking in India for Inclusive Growth and Social Uplift: Scopes and Challenges. International Journal of Business, Humanities and Technology Vol. 1 No. 1; July 2011.

6) Responsibility of Islamic Banks in Jordan. Euro Med Journal of Business, 11(1), 30-56. https://doi.org/10.1108/EMJB-01-2015-0003.

7) Hassan, A., Salma, H., \& Abdul, B. (2009). Corporate social responsibility of Islamic financial institutions and businesses, 25(3), 177-188. https://doi.org/10.1108/08288660910986900.

8) Khan, S. (2014). Islamic Banking for the Development of the Indian Economy, 6(9), 863868.

9) Majumdar. (2008). Islamic Banking in India What is the future potential.

10) Noor, W., Wan, H., \& Ibrahim, U. (2015). Corporate social responsibility of Islamic banks : Malaysian practitioners' perspective, (c).

11) Samina, Q. S. (2012). Practice of Corporate Social Responsibility in Islamic Banks of Bangladesh Samina, 2(6), 1-13.

12) Services, B. (2015). The Extent of Corporate Social Responsibility Engagement in Malaysian Banks Offering Islamic Banking Services, 20(2).

13) Singh, K. V., \& Sharma, N. (2013). Islamic Banking in India: A Roadmap, 1(1), 1-12.

14) Yazis, M., \& Basah, A. (2013). Islamic Bank and Corporate Social Responsibility ( CSR ), 5(11), 194-209. 